\title{
Secure Hash Algorithm-1
}

National Cancer Institute

\section{Source}

National Cancer Institute. Secure Hash Algorithm-1. NCI Thesaurus. Code C80225.

An algorithm for computing a condensed representation of a message or a data file that produces a 160-bit message digest. 